\title{
Designing Russian Teaching Material for University Students: Rationale and Mock Unit
}

\author{
Paola Bocale \\ University of Insubria, Como, Italy
}

\begin{abstract}
The aim of this study is to present some teaching materials that were developed to teach contemporary aspects of the Russian language. The methodology is based on the recognition of the central role played by spoken language in the construction of language teaching syllabuses. The first part of the study describes the rationale and justifies the design of the teaching units; the second part presents the text of a mock lesson.
\end{abstract}

Index Terms - materials development, contemporary Russian, colloquial language, input, output

\section{INTRODUCTION}

Fundamental developments have taken place in the Russian language in the last thirty years. The pace of change has been so rapid that Russian resource and coursebooks cannot always reflect the new linguistic scenario. Popular coursebooks often reflect features of the written language, whereas contemporary standard language, as described in reference books and coursebooks, does not coincide with the actual spoken usage.

The aim of this work is to present some teaching materials that were designed to teach contemporary aspects of the Russian language. The methodology is based on Carter and McCarthy's (2017) claim about the central role played by spoken language in the construction of language teaching syllabuses. In order to foster an appropriate transfer of discourse features across different languages, Carter and McCarthy maintain that learners have to develop cultural awareness; that is knowledge and recognition of cultural diversity and pluralism. This understanding can be achieved through exposure to authentic language material. For this reason, the teaching materials were developed using recordings of real conversations and examples of authentic language taken from publications or films which have appeared in Russia in the last decade.

\section{Methodology, Rationale ANd OBjectives of the Teaching Material}

The teaching material was written to take account of the changes in the Russian language which have occurred in the last thirty years. Throughout the units the emphasis is on building an understanding of contemporary features of Russian. The aim is to build up a "feel" for the language, in McCarthy's terms (1998). This is a matter of helping learners to invest energy and attention in discovering patterns and tendencies for themselves from guided investigations of samples of authentic language. This is particularly true for the teaching of Russian because Russian textbooks are often still based on a model of the language as it is presented in reference books.

The most significant developments in the Russian language in the last thirty years have taken place in the area of lexis. This is also because grammatical change as a rule proceeds at a much slower place (Wade \& Ryazanova-Clarke, 1999). For this reason, the teaching material focuses mainly on the new vocabulary, which is not only practised throughout each unit in a variety of activities, but also developed in its own section. However, because so many nonstandard elements (in the areas of lexis, pronunciation, and grammar) have inundated the standard language, tasks were developed which present and analyze these elements as well. Again, the aim is to give learners the possibility of developing the cultural awareness, or "feel," advocated by McCarthy.

Particularly relevant are the results of studies that investigated the merits of promoting learners' consciousness of grammatical forms (Ellis, 2003; McDonough, Shaw, \& Masuhara, 2013; Richards \& Rodgers, 2014). These studies demonstrated how raising students' observation of the rules and forms of a foreign language increases their acquisition and retention. Learning will be most effective when time is allocated for proper reflection on the linguistic structures. After having asked learners to focus on the meaning of structures, tutors should encourage them to pay attention to their form and functions. This process of observation, hypothesis formation, and production will result in effective acquisition and use of a target structure.

The units use and explore authentic examples (texts, audio, and visual material) of contemporary Russian. Their main aim is to provide learners and students of the language with the opportunity to see, hear, and understand it in a range of different contexts of use. The material was selected to make the learning of Russian stimulating and motivating for university students. 


\section{RESUltS AND ANALYSIS}

The units are designed for advanced and post-advanced learners of Russian. The intended audience for these units includes: undergraduate and postgraduates students of Russian language and linguistics, advanced learners of Russian as a foreign language, and A-level Russian language students.

The units can be used by tutors and learners in the following ways:

- as part of a complete course for learners of Russian at post-advanced level;

- to supplement a general Russian advanced course with material focusing on contemporary features of the language;

- as follow-up material for learners who have completed an advanced Russian course.

Each unit has a topical focus introduced through a reading and/or listening passage. Each lesson focuses on an indepth treatment of vocabulary, with clear presentations, explanation, and practice in the Vocabulary section, work on systems such as collocation, idioms, and word-building, and detailed explanation in the Study Boxes, followed by extensive practice activities. Within each unit, the aim was to exemplify the kind of vocabulary students are likely to encounter in everyday written and spoken Russian.

The material of the units was arranged to lead students from guided self-expression, both oral and written, based on advertisements, articles, dialogues, extracts from prose, instructions, and other sources, to free expression and composition on related topics.

The reading/listening/watching exercises develop the following skills:

- extracting relevant information;

- structuring information;

- inferring meaning from context;

- predicting and anticipating;

- understanding different registers;

- recognizing the function of different texts;

- recognizing discourse indicators and relations between parts of a text.

The speaking exercises include the following activities:

- role-play;

- discussion.

Units are divided into three sessions, each of which develops through passages, and exercises the themes and vocabulary of the unit. Transcripts of the recorded material are given at the end of each unit.

Each unit provides material for about six hours of classroom use. The units may be studied in any order and are not graded for difficulty. The Listening tasks and the Watching tasks given in the units are recorded on the accompanying CDs and video.

Each unit consists of the following sections:

Starting activity or "Warm-up":

Each unit begins with a short warm-up task, aimed at introducing the new language features of the module. In this starting activity, learners talk briefly in pairs or small groups, using or discussing individual elements of the new vocabulary. This prepares learners for the explanations of when and how to use the vocabulary which comes in the Vocabulary sections.

Listening to and/or watching passages and reading texts

Listening to passages and reading texts act as input for tasks, focusing on both informational content and language content. In turn, this input is used as the basis for output tasks, focusing on speaking and writing skills.

From a lexical point of view, different types of texts were chosen in order to provide different kinds of lexical input, in an attempt to balance what is most typical or frequent, and therefore potentially most useful, with what is most novel and unusual and, therefore, potentially interesting.

Vocabulary sections

The vocabulary sections focus on the following areas of vocabulary:

- youth slang;

- colloquial language;

- criminal slang;

- language used in advertising;

- idioms;

- non-standard features;

- borrowings;

- new words;

- collocations. 
Lewis' $(1993 ; 1997 ; 2000)$ lexical approach greatly influenced the design of the vocabulary sections. Lewis claims that language is made up of a number of assembled chunks which produce continuous text. These chunks are of various types: words, collocations (words which co-occur with greater frequency), fixed expressions (social greetings, politeness phrases, idioms), and semi-fixed expressions (expressions with a certain number of slots). In line with Lewis' lexical approach, attention was directed to introducing, whenever possible, larger chunks of language instead of words, and to focusing the presentation of the new vocabulary on collocations and expressions.

Speaking and/or writing sections

The output tasks were designed in line with research in the field of second language acquisition conducted by Swain (2005). While Krashen (1987) affirmed that speaking fluency cannot be taught directly, because speech emerges on its own as a result of competence built through understanding comprehensible input, Swain, without minimizing the role of input, showed that output plays a significant role as well. He hypothesized that in producing L2, learners become aware of a linguistic problem, and are thus pushed to modify their output. Noticing a gap in their knowledge forces learners into a more syntactic mode than might occur in comprehension.

Another second language theory which is relevant in the development of speaking tasks concerns the role of interaction. Long (1983) decided to study how input is made comprehensible. He investigated the ways learners interact with native speakers. His research revealed that in communicating with non-natives, native speakers systematically modify their speech and language behaviors in order to foster communication and increase mutual understanding. Besides linguistic simplification, other types of modifications are involved in modified interaction, including comprehension checks, clarification requests, paraphrases, "here-and-now" topics, expansions, and other linguistic adjustments (phonological, morphologic, syntactical, and semantic).

Long proposed the following model to describe the relationship between interactional modifications, comprehensible input, and language acquisition:

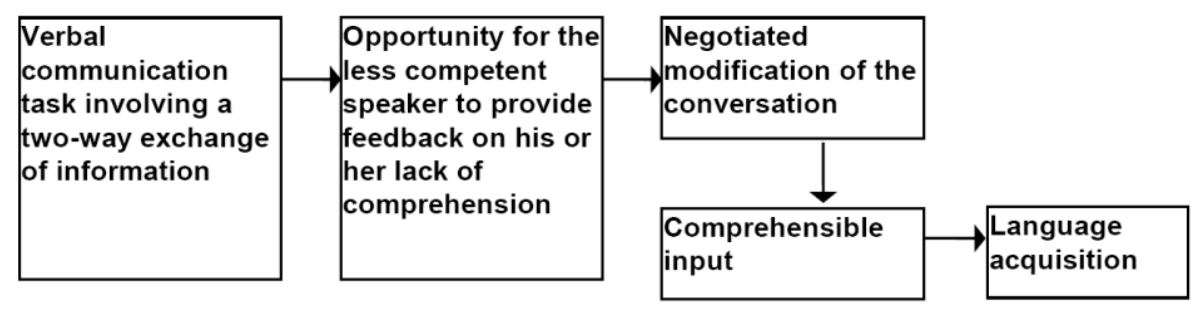

Figure 1: Long's model of the relationship between interactional modifications and language acquisition (Long, 1983, p. 214)

The model highlights the central role played by interaction and negotiation in the production of comprehensible input. Input modifications, namely linguistic simplification of input through less complex structures and vocabulary, are less useful to learners than modification which takes place during communication.

Study Boxes

These are meant to be explanations and clarifications which reinforce the vocabulary being taught. Learners can read them individually, in groups, or together as a class, after they have completed the starting activities. Alternatively, tutors may ask learners to read the Study Boxes at home or in class, before they do the starting activities (if the new vocabulary is particularly difficult for the class, for example). It is also possible for the relevant study box only to be referred to before or after learners perform each starting activity.

Exploring language sections

These sections feature language awareness activities based on the "Three Is" (illustration-interaction-induction) methodology proposed by McCarthy (1998). Learners look at real extracts of language, then with tutors analyze, discuss, and interpret the material. The rules governing linguistic phenomena are formulated and evaluated on the basis of observation and interpretation. Finally, conclusions are drawn about the features of the language analyzed.

Games

These are designed to be fun ways to consolidate and practise the new language introduced in the units.

\section{DISCUSSION AND CONCLUSION}

The present study looked at the central role played by spoken language in the construction of language teaching syllabuses. Mock units were trialed with the target students. The findings showed that units were evaluated as 'very appropriate' and that lessons were efficient in promoting interaction and learning of target structures.

In developing the teaching material, an analytical and communicative approach to learning through guided discovery was followed throughout. Substantial research, driven by the need to counterbalance communicative language teaching methodology with its focus on language use, revealed the benefits of improving learners' awareness and understanding of the forms of a target language. Swain (2005) suggests that output may have the function of forcing learners from the semantic processing prevalent in comprehension to the syntactic processing necessary for 
production. Producing language forces learners to reflect on what they do not know. This leads in turn either to a syntactic analysis of input, in order to look for missing structures, or to a reanalysis of existing internal linguistic resources, in order to fill the gap in knowledge. The speaking tasks were developed with the aim of creating opportunities for learners to be engaged in meaningful and mutually beneficial interaction.

Moreover, the speaking sections provided practice of functional language and that which is used in social situations, with a focus on different registers. There were a variety of communicative activities which provided extensive practice of the new vocabulary.

This research demonstrated the interrelation between input and interaction. The design of the teaching material was based on Vygotskian principles. According to Vygotsky, who worked in the Soviet Union in the 1920s and 1930s, cognitive development and learning are developed in a social context (Daniels, 2017). In the social environment of the classroom, students interact and learn from each other: those who are more able adjust their language and communications patterns to the needs of those who are less capable. Interactive activities, in the Vygotskian perspective, are of value because they provide learners with opportunities to understand foreign language input, and manipulate and modify their own output.

\title{
APPENDIX
}

\author{
Mock Unit 1 \\ Меняется жизнь, меняется речь... \\ Changing life, changing language ... \\ Часть 1
}

Session 1

Look at the article below, which discusses the changes which have occurred in the Russian language over the years.

Читайте статью, приведённую ниже. Она - об изменениях, которые произошли в русском языке в последние годы.

Язык мой - враг мой
Притихнув на некоторое время, споры о языке разгорелись вновь буквально в последние месяцы. Сразу на нескольких телеканалах прошли
передачи, посвященные этой проблеме. Особенно усердствует государственное РТР. В программе "Процесс" даже обсуждался вопрос о
введении специального закона. Закона, который карал бы со всей строгостью за нарушение правил произношения и грамматики. [...]
Меняется жизнь, и одновременно меняется речь. В том числе, за счет заимствований. "Модем" и "драйвер", они и в Африке - "модем" и
"драйвер". И ничего тут не поделаешь. В худшем случае, язык "расслаивается" на официально признанный "верх" и неофициальный,
народный "низ". Причем, "верх", лишенный подпитки "снизу", становится искусственным и постепенно засыхает, как засохла и умерла
средневековая латынь.
Власти дореволюционной России тоже предпринимали попытки хоть как-то проконтролировать развитие языка. Особенно в те времена, когда
режим взял на вооружение триаду "православие - самодержавие - народность". И все равно "мокроступы" не прижились, а "калоши" остались
"калошами". Этим словам не удалось стать даже синонимами. Вы можете представить себе моду на мокроступы? Зато мода на калоши была.
То же самое и теперь. Словечко "консенсус", к примеру, все реже употребляется в обычной речи, с газетных страниц оно перекочевало в
сугубо научные труды по социологии. Наши политики приходят к "согласию", заключают "соглашения" (на худой конец - "компромиссные").
(httр://samlib.ru/s/seregin s w/language.shtml last ассеssed 08.04.2020)

Discuss with two or three other students.

Обсуждайте вопросы, приведённые ниже, в группах из трёх или четырёх студентов.

A. Do you feel that your native language has changed during the last ten years? Has the use of words of foreign origin increased? Does your government take measures to discourage the use of new loan words?

Вы считаете, что ваш родной язык изменился за последние десять лет? Вырос ли число слов, заимствованных из других языков? Принимает ли ваше правительство меры для того, чтобы противостоять прониканию заимствований?

B. Does everyone who speaks your language speak it in exactly the same way? If not, how do the different styles vary - in accent, vocabulary, or grammar - or a combination of these? Give examples if you can.

Есть ли разновидность в формах речи носителей вашего языка? Есть ли разные стили? Чем они различаются? Произношением, словарным составом, грамматикой, или сочетанием всех этих элементов?

C. Does a person's style of speech depend simply on where they come from or is it also a matter of age, profession, and/or educational level?

На ваш взгляд разнообразие в стилях речи зависит только от происхождения людей или также связан с их возрастом, профессией и/или образованием?

D. Do you think people are beginning to use one particular style of speech more than any other nowadays? If so, which style and why are the changes occurring?

Вы находитесь, что люди стали теперь употреблять один стиль больше других? Если это так, какие могут быть причины этого?

Слушайте: Мнение Владимира Путина о роли и состоянии русского языка в современном мире 
Listening: Vladimir Putin's opinion on the role and condition of the Russian language in today's world

On November 5, 2019 Vladimir Putin held a meeting of the Council on the Russian Language, a consultative body established in 2014 to improve state policy in the development, protection, and support of the Russian language. In his opening address, President Putin expressed his concern about the issues facing the Russian language in the world today.

1 Listen to the beginning of Putin's speech and fill in the gaps below

(https://www.youtube.com/watch?v=w9NIXqMSnRA).

Прослушайте начало записи речи Путина и заполните предложения.

Добрый день, уважаемые коллеги, друзья!

Вначале позволю себе несколько слов сказать, как обычно.

Темы, которые мы обсуждаем и которые связаны с (1) языком, с русским языком, с (2) языком для России, относятся, безусловно, к наиболее важным темам как для (3) в целом, так и для каждого гражданина, для наших (4) и для миллионов людей по всему (5) которые говорят на (6) используют его в работе, в творчестве, в

2 Now continue listening to Putin's speech up until 1 minute 10 seconds and answer these questions.

Теперь прослушайте запись речи Путина до минуты 1.10 и ответьте на следующие вопросы.

а Какое место занимает русский язык в мировом культурном наследии?

б Какую роль играет русский язык в России?

в Какую главную опасность для русского языка Путин видит в современном мире?

Tapescript of Vladimir Putin's speech at the meeting of the Council on the Russian Language.

Транскрипция речи Владимира Путина на Заседании Совета по русскому языку.

Добрый день, уважаемые коллеги, друзья!

Вначале позволю себе несколько слов сказать, как обычно.

Темы, которые мы обсуждаем и которые связаны с родным языком, с русским языком, с государственным языком для России, относятся, безусловно, к наиболее важным темам как для страны в целом, так и для каждого гражданина, для наших соотечественников и для миллионов людей по всему миру, которые говорят на русском, используют его в работе, в творчестве, в общении.

Уникально богатый, многообразный, многогранный русский язык - безусловная часть мирового культурного наследия. Но главным, конечно, была и остаётся его значимость для нашей страны, для России, где он служит основой духовно-исторической общности десятков самобытных культур и народов в огромной степени обеспечивает суверенитет, единство и идентичность российской нации.

На нас, на нашей стране лежит громадная ответственность за сбережение, развитие и распространение русского языка, русской литературы, тем более сегодня, когда мы сталкиваемся с попытками искусственно - я хочу это подчеркнуть, - именно искусственно, грубо, подчас абсолютно бесцеремонно сократить пространство русского языка в мире, вытеснить его на периферию.

Словарь: Неологизмы

Vocabulary: new words

Look at the underlined words in these sentences and use both the context and what you know about the meaning of their constituent parts (prefix, root, suffix) to make a guess at what the word probably means.

Читайте слова, подчёркнутые в предложениях, приведённых ниже. Употребляйте контекст и ваши знания о составляющих их частях - их приставки, корни, суффиксы - чтобы угадать их значения.

а. Коммерцализация культуры, наступившая в связи с перестройкой, сказалась, увы, и на издательской деятельностью.

б. Разгосударствление промышленности серьёзно осложнено излишней осторожностью иностранных инвесторов.

в. Бросить все обычные дела и сооружать новые домостроительные комбинаты, такие, как у немцев (или как у французов). И, ей-ей, все равно, кто будет строить их: рыночник ли, антирыночник ли, коммунист, консерватор или радикал... Лишь бы поскорее. Стальной прут ведь не уговоришь: погоди, мол, железка, не лопайся (Ogonek 1991, 5 https://marquis-the-cat.livejournal.com/209694.html last accessed 07.04.2020)

г. Должны быть механизмы защиты некоммерческого кино.

д. Лекарства в списке самого сверхприбыльного бизнеса занимают третью строчку после наркотиков и оружия.

е. Распечатай на лазере одну копию красиво, а потом отксеришь.

ё. По сведениям экспертов родной табачной промышленности, наши отечественные сорта токсичнее «ненашних» почти в 20 раз. 
ж. (Корреспондент): - Кто занимается раскруткой альбома? (Певец): - Я сам себе продюсер. Скоро песни зазвучат по радио и ТВ.

3. Рекламная компания по продвижению товаров предоставила возможность передавать по телефону 59секундный рекламный радиоролик о своих продуктах.

Говорите: В стиле...

Speaking: In the style of ....

1 Here are some types of people and some topics for conversations. Check that you know the meanings of everything on the lists.

Ниже даются примеры разных типов людей и предметов для разговора. Проверьте, знаете ли вы значения всех слов?

$\begin{array}{llrrr}\text { студент } & \text { журналист } & \text { политикбухгалтер } & \text { молодая девушка } & \text { учитель } \\ \text { программист } & \text { спортсмен } & \text { адвокат торговец } & \text { пессимист } & \text { оптимист } \\ \text { акционер } & \text { предприниматель } & \text { домохозяйка } & \text { механик } & \text { поэт }\end{array}$

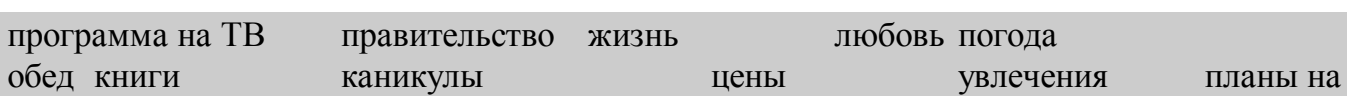

2 Follow these instructions.

Теперь работайте по этапам.

A. As a class, add four or more words or phrases to each of the lists in Exercise 1.

Работая всем классом, прибавьте несколько примеров к каждому списку в упражнении 1.

B. Discuss in twos or threes what you feel will be the special speech characteristics of each of the people in the first list and how this might influence the way they would talk about any one of the topics in the second list.

В группах из двух или трёх студентов обсуждайте характеристики людей в первом списке. Каким образом эти характеристики отражаются в том, как эти люди будут говорить о предметах второго списка?

3 Now you are ready to play the game.

Теперь вы можете играть.

A. Divide into two teams.

Разделитесь на две команды.

B. The tutor will give each person in each team a character chosen at random from the list. Do not tell anyone who your character is. The tutor then announces a topic and each person must decide how their character would talk about this topic.

Каждый член команд получит от преподавателя по типу, выбранному случайно из списка. После этого преподаватель объявит предмет и каждый член команд должен решить, как его тип будет говорить о данном предмете.

C. In turns, pairs of students - one from each team - role play their character's conversation on that topic.

По очереди студенты в парах (каждая пара состоит из членов разных команд) разыгрывают свой разговор перед классом.

D. After one to two minutes the conversation stops, and each team has three chances to guess who their team member's character was. If they identify the character in their first guess, then their team gets five points, if on their second guess, three points, and if on their third guess one point. If they do not get it right on their third guess, then the other team gets three points.

Через одну или две минуты разговор прекратится и у каждой команды есть три шанса, чтобы угадать кто был тип, разыгран членом их команды. Если они угадают с первой попытки, их команда получит пять баллов, если со второй попытки - три балла, а если с третьей - один балл. Если они не угадают с третьей попытки, команда противников получит три балла.

\section{Yacmь 2}

\section{Session 2}

\section{Читайте: Разновидность русского языка}

Reading: Varieties of Russian

1 Just as varieties of the spoken language are distinct, so are varieties of the written language. In this case it is a matter of where the text came from, for instance from a newspaper article, a novel, a poem, or another source. Most native speakers would be able to look at the extracts below and say what kind of source they came from. Can you do the same? In each case, say what type of text the extract comes from and explain how you were able to deduce this. 
Ниже приведены отрывки из разных текстов. Какие, по-вашему, источники этих текстов? Какие ключи в этих текстах подсказывают их источники?

F Система VOR (управляемой записи голоса) начинает и останавливает запись автоматически в соответствии со звуком для экономии ленты и заряда батареек. Функция SPEED CONTROL позволяет Вам повышать или понижать скорость воспроизведения ленты.

(https://www.sony.com/electronics/support/res/manuals/3862/38622037M.pdf last accessed 26.03.2020)

$<$

Яйца- молоко- соль- сахар и натертую лимонную цедру взбить (желательно с помощью миксера). Массу вылить на разогретую с маслом сковороду.

Когда яично- молочная смесь загустеет- на середину омлета выложить густое варенье- конфитюр или джем. Края омлета завернуть с двух сторон. С помощью ножа омлет швом вниз выложить на тарелку и посыпать сахарной пудрой. Омлет готовится порционно.

(https://www.russianfood.com/recipes/recipe.php?rid=94147 last accessed 26.03.2020)

\section{B}

Пока Земля ещё вертится, пока ещё ярок свет,

Господи, дай же ты каждому чего у него нет.

Умному дай голову, трусливому дай коня,

Дай счастливому денег и не забудь про меня.

Пока Земля ещё вертится, Господи, твоя власть,

Дай рвущемуся к власти навластвоваться всласть.

Дай передышку щедрому хоть до исхода дня,

Каину дай раскаянье и не забудь про меня.

(Okudžava 2012: 88)

$\Gamma$

Внутри, в удвоенной настенными зеркалами тесноте, размещалось несколько длинных вешалок с разнообразной джинсой и длинный стеллаж с обувью - главным образом кроссовками. Татарский, совсем как лермонтовский демон, окинул это кожано-резиновое великолепие скучающим взором, и на его высоком челе не отразилось ничего. Больше того, было вполне ясно: и тут кинули. Лет десять назад новая пара кроссовок, привезенная дальним родственником из-за бугра, становилась точкой отсчета нового периода в жизни - рисунок подошвы был подобием узора на ладони, по которому можно было предсказать будущее на год вперед. Счастье, которое можно было извлечь из такого приобретения, было безмерным. Теперь, чтобы заслужить право на такой же его объем, надо было покупать как минимум джип, а то и дом.

(V. Pelevin 2000: 9)

$\mathrm{L}$

23 сентября в 1100 в Зауральной роще Оренбурга стартует чемпионат области по легкоатлетическому кроссу. Для участия в соревнованиях приглашены сильнейшие спортсмены Оренбуржья. По итогам чемпионата будет сформирована сборная команда для участия в предстоящем чемпионате России.

(http://www.oreninform.ru/search/tag.php?q=легкоатлетический\%20кросс

last accessed 26.03.2020)

E

В числе принятых на минувшей неделе Госдумой законопроектов по судебной реформе был и новый вариант Закона "О Конституционном Суде РФ". В самом КС к некоторым положениям внесенного президентом законопроекта относятся прохладно. Прежде всего это касается предложения понизить статус членов КС, приравняв их ко всем прочим судьям.

(http://www.itogi.ru/archive/2001/26/104833.html last accessed 26.03.2020)

2 Now do some group work on the vocabulary of these texts.

Теперь работайте в группах на словарном составе этих текстов.

a. Work in five or six groups. Each group should take one of the above texts and underline all the words and expressions in it which are clues to the origin of the text. Make sure that you can explain what each of the underlined words and expressions means to other students in the class.

Разделитесь на пять или шесть групп. Каждая группа анализирует один из текстов. Подчеркните все слова и выражения, которые указывают на источник текста. Можете ли вы объяснять слова, которые вы подчеркнули, другим студентам в классе? 
b. Tell the class as a whole which words you underlined and explain the meanings of any words or expressions which any other student asks you to explain.

Сообщите другим студентам результаты анализа вашего текста. Ответьте на их вопросы.

Словарь: Словарные вилки

Vocabulary: Word forks

1 Look at the entry for поднимать in your dictionary. Find the right word to fill the gaps.

Читайте словарную статью на глагол поднимать в словаре русского языка. Вместо точек вставьте подходящие слова.

а. Я поднял и увидел воздушный шар.

б. Ливни подняли в реках.

в. Почуяв посторонных людей, собаки поднимают

г. Матерям-одиночкам трудно поднимать

д. В связи с напряжённой международной обстановкой предприниматели

е. В театрах после третьего звонка поднимаю

ё. Мой друг всегда поднимает наше

ж. Командир поднял смешными рассказами.

A word fork is a fork-shaped diagram like those below. A word fork helps you to write down three or more collocations (or words that frequently occur together) based on one word. Here are some examples, associated with the word направление.

Словарные вилки - это схемы, которые позволяют изображать графически сочетания слов. Ниже приведены примеры, связаны со словом направление.

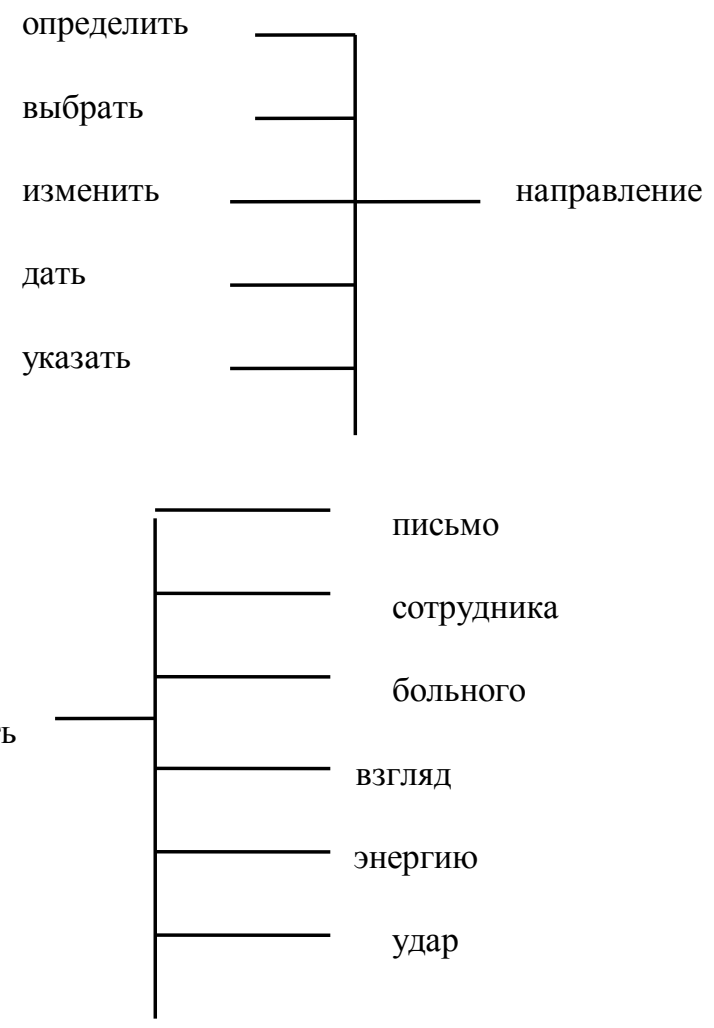

2 Choose one of the expressions from the направление/направлять word forks to complete these sentences.

Вместо точек вставьте подходящие сочетания слов, из числа приведённых выше.

а. Новое правительство

б. Начальник фирмы в международной политике.

в. Надо бизнеса.

г. Я пошёл на почту и

д. Саша встал и ой важной задачи.

Играем своему другу.

Game 
Divide into two teams. Each team has ten minutes to decide which is the language these loan words have been borrowed from. You will get one point for every right answer, but you will lose one point for a wrong one.

Разделитесь на две команды. У каждой команды десять минут, чтобы определить, от какого языка происходят эти заимствованные слова. Вы получите один балл за каждый правильный ответ, но потеряйте один балл за каждый неправильный.

\begin{tabular}{|c|c|c|c|c|c|c|c|c|}
\hline & $\begin{array}{l}\mathrm{a} \\
\text { Н } \\
\text { г } \\
\text { Л } \\
\text { и } \\
\text { й } \\
\mathrm{c} \\
\text { К } \\
\text { и } \\
\text { й }\end{array}$ & $\begin{array}{l}\phi \\
\mathrm{p} \\
\mathrm{a} \\
\text { Н } \\
\text { Ц } \\
\mathrm{y} \\
3 \\
\mathrm{c} \\
\text { К } \\
\text { и } \\
\text { й }\end{array}$ & $\begin{array}{l}\text { н } \\
\mathrm{e} \\
\mathrm{M} \\
\mathrm{e} \\
\text { Ц } \\
\text { К } \\
\text { и } \\
\text { й }\end{array}$ & $\begin{array}{l}\text { и } \\
\mathrm{c} \\
\text { П } \\
\mathrm{a} \\
\text { Н } \\
\mathrm{c} \\
\text { К } \\
\text { и } \\
\text { й }\end{array}$ & $\begin{array}{c}\text { и } \\
\text { Т } \\
\mathrm{a} \\
\text { Л } \\
\mathrm{b} \\
\text { Я } \\
\mathrm{H} \\
\mathrm{c} \\
\text { К } \\
\text { И } \\
\text { й }\end{array}$ & $\begin{array}{l}\text { П } \\
\mathrm{o} \\
\mathrm{p} \\
\mathrm{T} \\
\mathrm{y} \\
\Gamma \\
\mathrm{a} \\
\text { Л } \\
\mathrm{b} \\
\mathrm{c} \\
\mathrm{\kappa} \\
\text { и } \\
\text { й }\end{array}$ & $\begin{array}{l}\mathrm{T} \\
\mathrm{y} \\
\mathrm{p} \\
\mathrm{e} \\
\text { Ц } \\
\text { К } \\
\text { И } \\
\text { Й }\end{array}$ & $\begin{array}{l}\text { Я } \\
\text { П } \\
\text { о } \\
\text { Н } \\
\text { с } \\
\text { К } \\
\text { И } \\
\text { Й }\end{array}$ \\
\hline \multicolumn{9}{|l|}{ автобан } \\
\hline \multicolumn{9}{|l|}{ фазенда } \\
\hline \multicolumn{9}{|l|}{ имидж } \\
\hline \multicolumn{9}{|c|}{ консалтинг } \\
\hline \multicolumn{9}{|l|}{ хунта } \\
\hline \multicolumn{9}{|c|}{ компьютер } \\
\hline \multicolumn{9}{|l|}{ кайф } \\
\hline \multicolumn{9}{|l|}{ слаксы } \\
\hline \multicolumn{9}{|c|}{ папарацци } \\
\hline \multicolumn{9}{|l|}{ ноу-хау } \\
\hline \multicolumn{9}{|l|}{ софтвер } \\
\hline \multicolumn{9}{|l|}{ рэслинг } \\
\hline \multicolumn{9}{|l|}{ караоке } \\
\hline \multicolumn{9}{|l|}{ мафиози } \\
\hline \multicolumn{9}{|l|}{ плейер } \\
\hline \multicolumn{9}{|c|}{ паблик рилейшнз } \\
\hline \multicolumn{9}{|l|}{ бутик } \\
\hline \multicolumn{9}{|l|}{ холдинг } \\
\hline уоркмен & & & & & & & & \\
\hline
\end{tabular}

\section{Study Box \\ Заимствования \\ Lexical borrowing}

Although the predominant group of new words comes from English, there is a small number of words which have been recently borrowed from other languages. The most commonly used are бутик (French boutique), which has been adopted by stylists and designers to refer to high fashion shops, aвтобан "motorway" (German autobahn), папарацци (Italian paparazzi), and фазенда "ranch" (Portuguese fazenda), which derives from the very popular Latin American soap operas and is used ironically to mean "dacha, country house".

Loans from English

These are some examples from lexical areas where borrowing has been particularly active:

- the mass media

блокбастер 'blockbuster'

имидж 'image'

нюсьмеикер 'news maker'

масс-медия 'mass media'

таблоид 'tabloid'

телешопинг 'TV shopping'

- names of clothes and fashion анорак 'anorak'

бермуды 'Bermuda shorts'

бодu 'body-suit'

легинсы 'leggings'

слаксы 'slacks'

mon 'top'

- food

брану 'brunch'

гамбургер 'hamburger'

йогурm 'yoghurt'

крекер 'cracker'

корнфлекс 'cornflakes'

поридж 'porridge'

- new lifestyles

бунгало 'bungalow'

джакузи 'jacuzzi'

найт-клаб 'night club' плейбой 'playboy' 


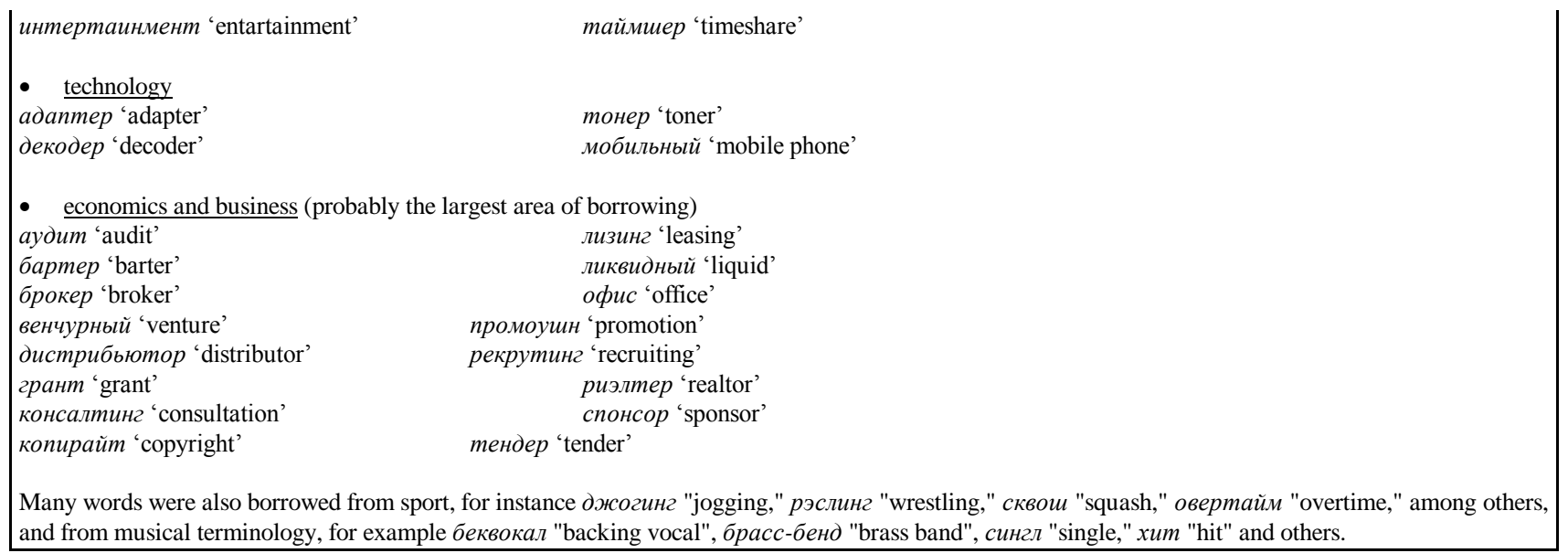

\section{Yacms 3}

Session 3

\section{Исследуем письменный язык: Проза В. Пелевина}

Exploring written language: The Prose of V. Pelevin

You are going to read an extract from Pelevin's novel Generation " $G$ ” (Pelevin, 2000). The novel's main character, Vavilen Tatarskii, builds his fortune working as a copywriter in the advertising industry. His job puts him in situations which are increasingly obscure and paradoxical.

Ниже приведётся отрывок из романа Виктора Пелевина Generation 'П', издан в 2000 г. Главный герой романа Вавилен Татарский делает блестящую карьеру работая для рекламных компаний. Но его работа ставит его в тёмных и парадоксальных обстановках.

1 Work in four groups. Each group has a short extract from the novel. Read your extract together, helping each other with any vocabulary problems.

Group A: Read extract A

Group B: Read extract B

Group C: Read extract B

Group D: Read extract $\Gamma$

Работайте в четырёх группах. Каждая группа читает отрывок из романа. Читайте ваш отрывок вместе и помогайте друг другу в разъяснении трудных слов.

Группа А: Читайте отрывок А

Группа Б: Читайте отрывок Б

Группа В: Читайте отрывок В

Группа Г: Читайте отрывок Г

2 When you have finished studying your extract, work in new groups. Describe your extracts and work out the order in which you think they occur (the extracts are not in the correct sequence). Then decide what happens to Vavilen Tatarskii.

Теперь работайте в новых группах. Опишите ваш отрывок и составьте правильную последовательность текста. Что случилось Вавилену Татарскому?

\section{A}

- Иду-иду, - долетел голос Азадовского, и он появился из прохода в какое-то внутреннее помещение. - Прибыл? Чего у дверей стоишь? Заходи, не съедим.

Татарский пошел ему навстречу. От Азадовского попахивало винцом; в галогенном свете его лицо выглядело усталым.

- Где мы? - спросил Татарский.

- Примерно сто метров под землей, район Останкинского пруда. Ты извини за повязочку и все дела - просто перед ритуалом так положено.

Традиции, мать их. Боишься?

Татарский кивнул, и Азадовский довольно засмеялся.

- Плюнь, - сказал он. - Это все туфта. Ты пока прогуляйся, посмотри новую коллекцию. Два дня как развесили. А у меня тут пара важных терок.

Он поднял руку и щелчком пальцев подозвал секретаршу.

- Вот Алла тебе и расскажет. Это Ваван Татарский. Знакомы? Покажи ему тут все, ладно?

Татарский остался в обществе секретарши.

- Откуда начнем осмотр? - спросила она с улыбкой.

- Отсюда и начнем, - сказал Татарский. - А где коллекция?

- Так вот она, - сказала секретарша, кивая на стену. - Это испанское собрание. Кого вы больше любите из великих испанцев?

- Это... - сказал Татарский, напряженно вспоминая подходящую фамилию, - Веласкеса.

- Я тоже без ума от старика, - сказала секретарша и посмотрела на него холодным зеленым глазом. - Я бы сказала, что это Сервантес кисти. 
Б

Когда с Татарского сняли повязку, он уже совершенно замерз. Особенно холодно было босым ступням на каменном полу. Открыв глаза, он увидел, что стоит в дверях просторного помещения, похожего на фойе кинотеатра, где, судя по всему, происходит нечто вроде фуршета. Он сразу заметил одну странность - в облицованных желтым камнем стенах не было ни одного окна, зато одна из стен была зеркальной, из-за чего освещенный яркими галогенными лампами зал казался значительно больше, чем был на самом деле. Собравшиеся в зале люди тихо переговаривались и разглядывали листы с машинописным текстом, развешанные по стенам. Несмотря на то что Татарский стоял в дверях совершенно голый, собравшиеся не обратили на него особого внимания - разве что равнодушно поглядели двое или трое. Татарский много раз видел по телевизору практически всех, кто находился в зале, но лично не знал никого, кроме Фарсука Сейфуль-Фарсейкина, стоявшего у стены с бокалом в руке. Еще он заметил секретаршу Азадовского Аллу, занятую разговором с двумя пожилыми плейбоями, - из-за распущенных белесых волос она походила на немного грешную медузу. Татарскому показалось, что где-то в толпе мелькнул клетчатый пиджак Морковина, но он сразу же потерял его из виду.

\section{B}

Она аккуратно взяла Татарского за локоть и, касаясь его голой ноги высоким бедром, повела к ближайшему листу бумаги на стене. Татарский увидел на нем пару абзацев текста и синюю печать. Секретарша близоруко нагнулась к листу, чтобы прочесть мелкий шрифт.

- Да, как раз это полотно. Довольно малоизвестный розовый вариант портрета инфанты. Здесь вы видите нотариальную справку, выданную фирмой "Оппенхайм энд Радлер", о том, что картина действительно была приобретена за семнадцать миллионов долларов в частном собрании.

Татарский решил не подавать виду, что его что-то удивляет. Да он, собственно, и не знал толком, удивляет его что-то или нет.

- А это? - спросил он, указывая на соседний лист бумаги с текстом и печатью.

- О, - сказала Алла, - это наша жемчужина. Это Гойя, мотив Махи с веером в саду. Приобретена в одном маленьком кастильском музее. Опятьтаки "Оппенхайм энд Радлер" не даст соврать - восемь с половиной миллионов. Изумительно.

- Да, - сказал Татарский. - Правда. Но меня, честно говоря, гораздо больше привлекает скульптура, чем живопись.

- Еще бы, - сказала секретарша. - Это потому что в трех измерениях привыкли работать, да?

Татарский вопросительно посмотрел на нее.

- Ну, трехмерная графика. С бобками этими..

- А, - сказал Татарский, - вы вот про что. Да, и работать привык, и жить.

$\Gamma$

- Вот и скульптура, - сказала секретарша и подтащила Татарского к новому бумажному листу, где текста было чуть побольше, чем на остальных. - Это Пикассо. Керамическая фигурка бегущей женщины. Не очень похоже на Пикассо, вы скажете? Правильно. Но это потому, что посткубистический период. Тринадцать миллионов долларов почти, можете себе представить?

- А сама статуя где?

- Даже не знаю, - пожала плечами секретарша. - Наверно, на складе каком-нибудь. А если посмотреть хотите, как выглядит, то вон каталог лежит на столике.

- А какая разница, где статуя?

Татарский обернулся. Сзади незаметно подошел Азадовский.

- Может, и никакой, - сказал Татарский. - Я, по правде сказать, первый раз сталкиваюсь с коллекцией такого направления.

- Это самая актуальная тенденция в дизайне, - сказала секретарша. - Монетаристический минимализм. Родился, кстати, у нас в России.

- Иди погуляй, - сказал ей Азадовский и повернулся к Татарскому: - Нравится?

- Интересно. Только не очень понятно.

- А я объясню, - сказал Азадовский. - Это гребаное испанское собрание стоит где-то двести миллионов долларов. И еще тысяч сто на искусствоведов ушло. Какую картину можно, какая будет не на месте, в какой последовательности вешать и так далее. Все, что упомянуто в накладных, куплено. Но если привезти сюда эти картины и статуи, а там еще гобелены какие-то есть и доспехи, тут пройти будет негде. От одной пыли задохнешься. И потом... Честно сказать - ну, раз посмотрел на эти картины, ну два, а потом - чего ты нового увидишь?

- Ничего.

- Именно. Так зачем их у себя-то держать? А Пикассо этот, по-моему, вообще мудак полный.

- Здесь я не вполне соглашусь, - сглотнув, сказал Татарский. - Или, точнее, соглашусь, но только начиная с посткубистического периода.

- Я смотрю, ты башковитый, - сказал Азадовский. - А я вот не рублю. Да и на фига это надо? Через неделю уже французская коллекция будет.

Вот и подумай - в одной разберешься, а через неделю увезут, другую повесят - опять, что ли, разбираться? Зачем?

Татарский не нашелся, что ответить.

- Вот я и говорю, незачем, - констатировал Азадовский. - Ладно, пошли. Пора начинать. Мы потом сюда еще вернемся. Шампанского выпить.

\section{REFERENCES}

[1] Carter, R., McCarthy, M. (2017). Spoken Grammar: Where Are We and Where Are We Going? Applied Linguistics, 38 (1), $1-20$.

[2] Daniels, H. (2017). An introduction to Vygotsky. ( $3^{\text {rd }}$ ed.). London: Routledge.

[3] Ellis, R. (2003). Task-based language learning and teaching. Oxford: Oxford University Press.

[4] Krashen, S. (1982). Principles and practice in second language acquisition. London: Pergamon Press.

[5] Lewis, M. (1993). The Lexical Approach. Hove: Language Teaching Publications.

[6] Lewis, M. (1997). Implementing the Lexical Approach. Hove: Language Teaching Publications.

[7] Lewis, M. (2000). Teaching Collocation: Further Developments in the Lexical Approach. Hove: Language Teaching Publications.

[8] Long, M.H. (1983). Native speaker/non-native speaker conversation in the second language classroom. In M.A. Clarke and J. Handscombe (eds.) On TESOL '82: Pacific perspectives on language learning and teaching. Washington, 207-25.

[9] McCarthy, M. (1998). Spoken language and applied linguistics. Cambridge: Cambridge University Press.

[10] McDonough, J., Shaw, C., Masuhara, H. (2013). Materials and methods in ELT: A teacher's guide. Oxford: Blackwell. 
[11] Okudžava, B. (2012). Poka zemlja ešče vertitsja. Moskva: Azbuka.

[12] Pelevin, V. (2000). Generation P. Moskva: Vagrius.

[13] Richards, J.C., Rodgers, T.S. (2014). Approaches and methods in language teaching. $3^{\text {rd }}$ ed. Cambridge: Cambridge University Press.

[14] Swain, M. (2005). The output hypothesis: theory and research. In E. Hinkel (ed.), Handbook of Research in Second Language Teaching and Learning. New York: Routledge, 471-483.

[15] Wade, T. and Ryazanova-Clarke, L. (1999). The Russian Language Today. London: Taylor and Francis.

Paola Bocale is Associate Professor in Slavic Studies and Director of the Centre for Research on Minorities (CERM) at the University of Insubria. Her main research interests are corpus linguistics, SLA, sociolinguistics, and pragmatics. 